\title{
7: Myanmar education: challenges, prospects and options
}

\author{
Han Tin
}

\section{The setting: the land and its people}

Traditionally, five pillars make up Myanmar society: farmers, workers, students, monks and the military. All Myanmar children who have attended school are aware of these five pillars because of the pantheon of national heroes revered throughout the nation. Farmers are represented by Saya San, who led the Peasant Revolt; $^{1}$ workers by Thakin Po Hla Gyi, who led the oil-workers' strike; ${ }^{2}$ students by Bo Aung Gyaw, an early student leader; ${ }^{3}$ the monks by U Wisara, who was martyred in a British jail; ${ }^{4}$ and the military (Tatmadaw) by Bogyoke Aung San, the founding father of the Tatmadaw and the architect of Myanmar's independence. ${ }^{5}$ All of them struggled against the colonial power with the common goal of gaining freedom and independence. These five pillars are potent symbolic forces and together they achieved the creation of an independent nation. It is important now more than ever that these five pillars of Myanmar society again create an atmosphere of empathy and trust and work towards the common goal of developing the nation. Such a symbiotic relationship among these five groups is sorely needed in Myanmar at present.

Myanmar has, since independence, prided itself on its values of self-help and self-reliance. For many decades, it has been going its own way. For the country to evolve and take its place in the world as a modern developed nation, self-reliance alone is not enough. Greater efforts on Myanmar's part, together with empathy, cooperation and assistance from the world community, are most necessary. Myanmar has some means, but they are limited. It needs understanding and support from the international community. It needs encouragement to begin developing a system of good governance that will see the nation again take its place in the family of nations. The onus is, however, also on Myanmar to initiate changes to move away from a 'dominator'-type of society towards a more tolerant, liberal one.

During the previous century, many countries in Asia-such as South Korea, Indonesia, the Philippines and Japan — emerged from authoritarian and militaristic moulds of government and embraced a more liberal form of governance. Myanmar, which has had an extreme authoritarian government since the early 1960s, as well as suffering the indignity of colonial rule and the long legacy of rule by extreme authoritarian kings and feudal lords, is finding it extremely 
difficult to break out of the mould. As has been the case throughout Myanmar's history, its people, in spite of their hardship, distress and anguish, hope for a better life. To break the mould of authoritarianism, the very psyche of the population will have to evolve - but not at the expense of its culture, traditions, customs and values.

In this respect, education has much to offer, for it plays an important role in the personal and social development of the young, who represent the future. The International Commission on Education stresses this fact in its report to the UN Educational, Scientific and Cultural Organisation (UNESCO). It states: 'Getting the reform strategies right, by a broad-based dialogue, and by increasing responsibility and involvement of stakeholders at every level, will be a crucial element of educational renewal' (UNESCO 1996:26).

\section{Myanmar education: the roles of the stakeholders}

The major stakeholders in education are parents, teachers and students. The success or failure of the education process depends on the interaction of these three groups and the changing roles they play in, or are assigned by, the society in which they live. In addition, they are affected by government policies and the influences of religious institutions such as monasteries, churches and mosques. Most importantly, however, it is the interactions of the child with the teacher in the contexts of the school and the community and with the parents and the family in the contexts of the home and the community that determine the outcome of the child's education. Such relationships among the stakeholders are pivotal to creating the kind of cultural change necessary to sustain a post-authoritarian society. As such, the roles of teachers, parents and students will be discussed.

\section{The role of teachers}

Philosophies such as Buddhism and Confucianism advocate the enhancement and glorification of filial piety: the respect and devotion of an individual for their parents and teachers. In a predominantly Buddhist country such as Myanmar, teachers have traditionally been regarded as one of the 'five gems' and considered on the same plane as the Buddha (who himself was a teacher), the Scriptures, monks and parents. In such societies, teachers assume the role of substitute parents. This places a great amount of responsibility on them. The social roles of teachers and students are drawn so rigidly that expecting the latter to participate in dialogue and decision making is often deemed inappropriate (Han Tin 2004). Similarly, in other spheres of Myanmar life, especially where hierarchies exist, as in the military, in the monasteries and in instances in which superior-subordinate relationships occur, the divisions are rigidly drawn. The commands or orders of a superior are almost never questioned or challenged. It is, however, an experienced reality in education that teachers 
can, and do, have life-influencing effects on students. Many individuals who have succeeded in life invariably attribute their success to one or more of their teachers, who are remembered with much respect, affection and gratitude.

Teachers have great potential to act as agents of change. Teachers are, however, as a group, highly conservative and traditionalist, and tend to resist change. For instance, the two Departments of Basic Education ${ }^{6}$ and the Myanmar Education Research Bureau have held training sessions on new methodologies and classroom strategies to counter rote learning but with little success. When the teachers returned to their classrooms, they reverted to their old methods after a time. This indicates the need to change the attitude of teachers by improving methods of teacher training - pre-service and in-service - and further increasing their professionalism. Teachers are crucial players in any endeavour to create a more enlightened population. Kennedy (1998) has pointed out that 'outcomes of education are affected by the quality of the teaching workforce. Well-qualified and committed teachers will make the difference between success and failure for many students.'

At a time in Myanmar's education system when the dedication, commitment, confidence and high social status of teachers are being eroded by malpractice and corruption, it is clear that corrective measures must be taken without delay to arrest this backslide. As Hattie (2004) remarked, 'it is what teachers know, do and care about which is very powerful to the teaching-learning equation'. Teachers have one of the most significant influences on the learning of students.

The function of teachers is essential, as they have to inculcate important values in future generations and ensure the holistic development of their students. The best teachers strive continuously to develop in their students respect for other races, other cultures, other religions, other conventions, other traditions and other points of view. They are aware of the moral or conventional nature of social values that are to be employed in character education and 'values lessons'. It follows that the training of teachers should also include the pursuit of moral, intellectual and aesthetic virtues and their acquisition. The major task of teachers would then be to impart these virtues to their students in addition to the main task of teaching the standard school subjects. Until the early 1960s, school activities included 'pyi thu ni ti' (lessons on civics, ethics and good citizenship). This was very much in line with present-day 'affective education', 'values education' and 'character education'. To make headway in an attempt to reduce the corruption that exists in all work environments at all levels, lessons on ethics with emphasis on honesty and trust should be reintroduced in schools.

Teachers occupy a unique and influential role in Myanmar society and have the potential to act as agents of social change; imbuing their students with liberal and humanistic values and ideals so that when they become parents they will be less authoritarian and will bring about a movement away from the 
authoritarian model of social relations that exists in Myanmar. In addition to this, teachers have the potential to use their status in the community to try to interact with parents and influence them in such a way that they will be less authoritarian towards their children. By changing the mind-set of parents, teachers will be making it possible for future generations to move away from the dominator-type of society that exists today.

\section{The role of parents/families}

Children are born into the nation, the religion and the social class with which their family identifies. Few will dispute the power of the family as a socialising agent. Religion and moral codes tend to support traditional views, especially the dominant position of the father in the family and the special reverence accorded to motherhood in orthodox Burmese Buddhist families.

In Myanmar, financial constraints often discourage many poor parents from sending some or all of their children to school. Often these parents keep their children gainfully employed to supplement the family income, or keep them at home to look after their younger siblings while both parents are away at work in the fields or elsewhere. Such a scenario is true of many of the poor communities in rural areas.

A different picture emerges from the cities and towns. Most urban parents are aware that their children stand a better chance of succeeding in life with an education. Many parents strive (in many cases, beyond their means) to send their children to the best schools to obtain what they hope will be quality education. A worrying feature that is emerging is that some rural families have shifted towards urban areas because of the belief - real or imagined - that more job opportunities exist in the cities. This author has previously (Han Tin 1994) pointed out that most of the rural families who leave their villages often settle in peri-urban areas or satellite towns. Due to the high cost of living in cities, both parents invariably have to work to make ends meet and the children are left to their own devices. Also, the disruption from traditional village life deprives them of the support of the 'extended family' and the village monastery. The resulting disorientation often leads to antisocial behaviour and, ultimately, these children find themselves in the most vulnerable group of the population and their parents' expectations are seldom realised. Fortunately, migration from rural to urban areas in Myanmar has not been excessive. Urbanisation in Myanmar still appears to be slow. According to the latest UNESCO Institute of Statistics estimates (based on World Bank development indicators), the rural population for 2005 was still 69 per cent of the total.

\section{The role of students}

The largest and the most important stakeholders in education are the students. According to the UNESCO Institute of Statistics (2007), of a total population of 
48379000 , the group aged from birth to 14 years makes up 25 per cent. Since 1988, when Myanmar emerged from self-imposed isolation of 26 years, the young people of Myanmar have become increasingly aware of what life has to offer. At the post-school level in the cities, the expectations of these young people are more varied as well as being more focused than previous generations. Most feel that the schooling they have received has failed to prepare them for the world of work. With the support of their families, they are willing to invest in courses that provide them with learning and skills that will enable them to strive for upward mobility. This is attested to by the popularity and success of private, non-government educational establishments, which have sprung up throughout Myanmar (see chapters by Lorch and Lall in this volume). Though such institutions have taken up the 'slack' in educational provision, the motives of some of these privately run establishments are rather dubious. Quality control is a necessity in these circumstances. Accreditation and recognition must be given by a professional body, which should be non-governmental, but with Ministry of Education representation.

\section{The education process}

The process of education is concerned chiefly with the interaction between the teacher and the child together with the classroom practices that occur within the school environment. Peer pressure is also an important factor in shaping a child's behaviour. Parents within the context of the family and home provide the child with the security, support and guidance necessary for his or her proper intellectual and moral growth. Religion, in the form of monasteries, churches and mosques, also has a great influence on the socialisation of the young. There are close interconnections between the institution of family, the institution of religion and the institution of education. They act as partners in reinforcing the social education of the young. Teachers, parents and religious leaders have a moral responsibility to pass on values and principles to children. Most interventions in the provision of education occur at the policy, structural, school or home levels. More importantly, however, it is what the young people learn from the home and school environments that shapes their personality and character.

\section{Issues in Myanmar education}

The Education Sector Study (ESS), a collaborative effort of the Ministry of Education, UNESCO and the UN Development Program (UNDP), was a watershed in the development of education in Myanmar. The ESS was begun in 1990 and Phase I-Final Report (of the diagnostic phase) was completed in 1992. In 1993, Phase II-Proposals for Education Sector Development (volumes one and two) were published. The ESS identified a number of key issues for reform and 
presented them in terms of broad priority areas. The eight key issues identified for development of the education sector in Myanmar are:

- redefining the role of primary education

- strengthening curriculum development to meet changing needs

- creating a fair and efficient selection system

- making evaluation learning oriented

- linking education to life after school and the world of work

- improving the quality of teaching and training of teachers

- providing appropriate facilities and instructional materials

- improving sector management.

Although efforts have been made to address the issues identified by the ESS, they have mostly been inadequate. New methodologies and school textbooks have been introduced and tried, but rote learning is still the method preferred by teachers and students. The existing examination and assessment systems still encourage memorisation of facts, which has stifled attempts to instil analytical and creative thinking. The 11 years of primary and secondary education culminate in the matriculation examination, which is conducted on a nationwide scale. Due to attempts to control malpractice and corruption, things have improved; however, rote learning still exists, although to a lesser extent. It is detrimental to the integrity of the system when candidates still scramble to 'buy' sets of questions for approaching examinations.

Curriculum reform is an issue that also needs to be addressed urgently. The current curriculum is so overloaded with factual knowledge that it lends itself to rote learning. Classroom practices also do not allow for analytical, creative thinking or free discussion and expression of thought.

There has, however, been an important improvement to the school curriculum. With the support of the UN International Children's Emergency Fund (UNICEF) and the Myanmar National AIDS Program, a HIV/AIDS prevention and 'healthy living' curriculum has been introduced in primary and secondary schools nationwide, helping millions of children gain knowledge and develop skills that can help them stay healthy. As a result, thousands of lives that would otherwise have been lost will be saved.

Education in Myanmar still faces issues identified by the ESS and only massive investment by the government and international organisations will enable the education sector to contribute positively towards national development.

\section{Prospects and options}

Much has been said and written about how poorly Myanmar education is doing. There are, indeed, problems in all levels of education. At the preschool level, an atmosphere of benign neglect exists. There is only a rudimentary and limited 
teacher-training program for preschool teachers and care givers. The lack of control, standards and training of teachers is evident from the ad hoc system of schools in which three to four-year-olds are being taught the school curriculum of higher grades by rote learning. The joy of learning and the idea that school can be a place for socialising and fun as well as for learning are stifled from the very outset of a child's life. Most preschools are overcrowded and badly managed. Much will have to be done to ensure quality and acceptable standards.

At present, education in Myanmar is structured into five years of primary school, four years of middle school and two years of high school. In effect, a child receives 11 years of schooling (kindergarten and standards one to 10) before entering tertiary education. Kindergarten is taken to be part of the primary education cycle making it a de facto 'standard one'. A Myanmar child starts his or her schooling at five years of age and takes his or her matriculation examination at 16 years of age. This system needs to be reformed. The state school system should treat kindergarten as a nursery and school proper should start at standard one, and the cycle should run for 12 years.

Since 69 per cent (UIS 2007) of the population lives in rural areas and approximately 64.1 per cent are employed in the agricultural sector, provision of education to these rural communities should be geared towards their needs. The curriculum and programs used in rural schools should be flexible not rigid. The rigid, monolithic national curriculum, school terms and timetables that exist today will have to be reconsidered. For rural areas, a more flexible curriculum based on local needs should be devised and, where seasonal cropping occurs, school terms should be arranged so that rural family units can make full use of the manpower available to them without disrupting the schooling of their children. In such a way, the massive drop-out rate before completion of the primary cycle of education can be staunched in these disadvantaged areas. If rural schools are programmed as urban schools are and the plight of agrarian families is ignored, the pernicious effect of school drop-out rates on the already weakened education system will be increased further. It will no longer be state education for the masses, but for the elite. Furthermore, the Education Management Information System (EMIS), which has been set up by the Department of Basic Education, should carry out further school-mapping exercises and work out the needs of local communities in rural areas. An urban-school model does not usually work well in a rural setting. A realistic specification of needs for rural areas has to be undertaken and implemented urgently.

It is generally accepted that education, health, agricultural and rural development are the keys to social, economic and environmental reforms in Myanmar. Focus must also be placed on education with an agricultural bias. Kyaw Than (2006) says that Myanmar has 10 agricultural high schools, seven state agricultural institutes and one university of agriculture. It is sad to note, however, that, at 
present, some agricultural high schools have closed due to the paucity of student intake. This is a sorry state of affairs in an agricultural country such as Myanmar. It could be that the curriculum is too esoteric and is perceived as being of little intrinsic value by those for whom the schools are intended. The situation might improve if agricultural education is decentralised and local education councils are formed and given the room to fit courses to local needs. There should also be more 'hands-on' experience shared by agricultural extension personnel with local communities. Collaboration and participation by farmers are essential. They must be provided with practical solutions to their problems. The main thrust should be on improving the productivity of the crops that the poor consume. There is a need to target the areas where the largest numbers of poor people live (Win and Batten 2006). The Asian Development Bank (ADB 2007) supports this: 'In view of the importance of agriculture and its impact on poverty, strengthening the sector should be a key goal.'

Currently, agriculture is losing out as the nation's focus is directed towards exploring for natural gas, gemstones and minerals. This is unfortunate, as these resources are finite. On the other hand, agricultural productivity-like human resources - is a renewable factor. Much more should be done for the sons and daughters of rural folk engaged in agriculture. The farmers themselves should also be given an opportunity to gain literacy skills and therefore be able to participate more effectively in agricultural extension endeavours. The Community Learning Centre (CLC) initiative begun by the Myanmar Education Research Bureau (MERB) offers those with no literacy a chance to go from 'darkness into light'. So far, 71 CLCs have been established under the UNDP's Human Development Initiative (HDI) project. Other non-governmental organisations (NGOs), local and international, have joined the effort. According to MERB, there are now 480 CLCs.

Literacy-promotion programs are not new to Myanmar. In the late 1960s, a national campaign known as 'the three rs' was undertaken, involving university students and people from all walks of life - monks, workers, farmers and armed forces personnel. The campaign was deemed a success and lauded by UNESCO, which, in 1971 and 1983, awarded Myanmar its prize for literacy activities.

This important undertaking can be replicated with the cooperation of the five pillars of Myanmar society; however, the campaign model will have to be updated. Incentives must be provided for those illiterate people who join the programs. For example, a farmer who gains literacy through these programs must be rewarded. The reward should not be just a paper certificate, but micro-credit points towards his children's education. In this way, the father (who invariably is the dominant member of the family) will take pride in his own 'education' and feel satisfied that he is also contributing to his children's education. This will go a long way towards alleviating the problem of large 
numbers of drop-outs and the non-completion of even the primary cycle of education.

The importance of the professional training of teachers has been stressed repeatedly, but training alone is hardly the answer. Adequate remuneration and incentives must be provided to counter the dubious practices of some of teachers 'to earn a fast buck' by operating outside the formal state system. All this highlights the need for teachers to be better trained and to be more professional. There must be a substantial investment by the Ministry of Education in the training and retention of teachers. It is a major concern when the trust and high regard that parents and students once had for their teachers are being worn away by economic pressure, which is being felt at all levels of society. The status of teachers must also be reviewed in terms of increased salaries, allowances and fringe benefits. Their standing in terms of the hierarchy for public employees and the civil service must also be greatly improved. The teaching profession must be made to appear attractive so that a higher calibre of people will be inclined to enter it. Only by being helped to do the right thing will Myanmar teachers regain their rightful place as one of the 'five gems'.

As Myanmar slowly develops, in spite of its handicaps, it will need an increasingly larger workforce of mid-level technicians with hands-on experience and skills. The former Department of Technical, Agricultural and Vocational Education (DTAVE) was effective in the training of such manpower in the past. Many of its staff members were trained at the Colombo Plan Staff College in Singapore. The emphasis then was to produce mid-level technicians with usable and marketable skills. There is a need to return to a vocational system of education that serves the needs of the industrial and construction sectors.

\section{Challenges for tertiary education: options}

Many comments have been made about university education in Myanmar, most of them negative. Too much stress has been placed on a very rapid quantitative expansion with quality standards and control lagging behind. The number of higher-education institutes functioning under various ministries and the Civil Service Selection and Training Board increased from 32 in 1988 to 156 in 2008 (Table 7.1).

The rationale behind this expansion is to promote equitable educational development and access among the various regions in Myanmar. Today every state and division has a minimum of three higher-education institutes to cater to its needs. This is highly laudable, but the running costs of such institutes are extremely high and the budget allocation for most ministries is limited. There are inequities among the ministries resulting in institutes under the better-funded ones - such as defence, forestry and agriculture and irrigation-being better staffed, better equipped and better organised. As for the higher-education 
institutes under the Ministry of Education, the budget allocation is limited. Furthermore, this budget has to be distributed among the 10 departments under it. The reallocated budget for the two higher-education departments is then shared by the 64 universities, institutes and colleges under them.

Table 7.1 Number of higher-education institutions in Myanmar (2008)

\begin{tabular}{|c|l|c|}
\hline \multicolumn{1}{|c|}{ Ministry } & Number \\
\hline 1 & Education & 64 \\
\hline 2 & Health & 14 \\
\hline 3 & Science and technology & 56 \\
\hline 4 & Defence & 5 \\
\hline 5 & Culture & 2 \\
\hline 6 & Forestry & 1 \\
\hline 8 & Agriculture and irrigation & 1 \\
\hline 9 & Livestock, breeding and fisheries & 1 \\
\hline 10 & Civil Service Selection and Training Board & 5 \\
\hline 11 & Religious affairs & 1 \\
\hline 12 & Progress of border areas and national races and development affairs & 2 \\
\hline 13 & Transport & 1 \\
\hline & & $\mathbf{1 5 6}$ \\
\hline
\end{tabular}

Source: Compiled by author.

Shortages of equipment and teaching materials, and more importantly the shortage of teaching as well as support staff, have adversely affected the standards of the new universities and higher-education institutes under the Ministry of Education. Much investment and effort will have to be made in order to regain the high standards achieved in the 1950s and 1960s by the two national universities of Yangon and Mandalay. Previously, degrees from these two universities were recognised internationally and their graduates were accepted for postgraduate studies by universities in the West and elsewhere. To achieve the high standards of these universities once again and to gain recognition and accreditation for their degrees would be beyond the present capabilities of the new universities. Recognition of some degrees has become problematic, even within the country itself. University of Distance Education graduates, for example, are finding it increasingly difficult to be competitive in the job market.

Research and development have also lagged behind due to inadequate funds. Although Myanmar's universities and tertiary education institutes have neither the time nor the money to engage in a 'theoretical treasure hunt', they should still try to recruit the best brains in the country.

The present trend towards computer literacy and the emphasis on information technology (IT) should be further strengthened. The establishment of Myanmar Information and Communication Technology Centres in Yangon and Mandalay is a progressive step. The proximity of Myanmar to India, and the extremely 
cordial relations that exist between the two countries, makes it attractive to tap the international 'outsourcing market', which has boosted the Indian economy. To do so, however, will require a steady and reliable source of energy. International assistance and loans would be essential to set up a national electricity grid. It is in the interest of the world community to strengthen the IT industry in Myanmar, as it will allow the country to make a quantum leap into the twenty-first century. As in its neighbour China, in Myanmar, free access to the Internet has yet to occur; however, 'cyber cafes' in the major cities have made email links with other countries possible for the general public.

According to Kyaw Than (2006), the Yezin Agricultural University is better staffed than most other institutions. Fifty-two per cent of its faculty have postgraduate degrees from various foreign countries. Furthermore, 180 of its new graduates are being sent annually to Arava Company Limited in Israel for 11 months' on-the-job training and to undertake a diploma course in agribusiness studies. Surely, such a program could be replicated for other universities and tertiary education institutes.

Sanctions and threats from some quarters of the international community are not working and should not be allowed to continue because the plight of the people of Myanmar is getting worse day by day. It is time to move forward. In this matter, could not the Association of South-East Nations (ASEAN) play a leading role? Cooperation and assistance from other nations should be increased. The main thrust should be in the sectors of health and education. The constructive engagement policies of Australia, Japan and ASEAN nations should be taken further.

Commonwealth countries initiated the 'Colombo Plan' after World War II to provide cooperation and assistance to South Asian nations. It was later enlarged to embrace other South-East Asian nations. The plan contributed much towards the development of member nations and Australia took an active and leading role in it. Myanmar was one of the Colombo Plan nations. If a similar plan could be initiated by the ASEAN states, with inputs from developed nations together with the two economic powers of Asia - China and India - much headway could be made.

\section{Conclusion}

Much remains to be done to restore Myanmar education to its former high standards. In order to achieve this, a holistic approach to education must be taken. The focus should be not only on formal education, but on informal education. Informal education via the mass media and popular literature is often forgotten when discussing education issues. It is highly effective in educating the general populace about social problems such as drug addiction, sexually transmitted diseases and the existence and spread of HIV/AIDS. In such a holistic 
approach, the needs and inputs of the major education stakeholders must be considered within the contexts of home and community and school and community. Religion and the policy environment will also influence the outcome of the education process.

Finally, Myanmar education will improve only when the education and training of its young improves. Their education should be carefully planned and mapped out. This chapter has identified the various stages in the education of a child and the development of its behaviour at which interventions could be made to establish habits of thoughtfulness, emotional discipline, self-management and conflict resolution. Only with such interventions will an evolutionary process begin in the mind-set of the population, making it possible for change to occur. Underpinning all this is a need for generational change, which will transform the psyche of the whole nation and enable its society to move away from a dominator type towards a more liberal and freer one.

\section{References}

Asian Development Bank (ADB) 2007, Asian Development Outlook 2007, Asian Development Bank, Hong Kong.

Akimoto, Y. 2006, Opportunities and Pitfalls: Preparing for Burma's economic transition, Open Society Institute, New York.

Asia Pacific Centre for Educational Innovation and Development 1999, Secondary Education and Youths at the Crossroads, UNESCO PROAP, Bangkok.

Asia Pacific Network for International Education and Values Education 2002, Learning To Be: A holistic and integrated approach to values education for human development, UNESCO PROAP, Bangkok.

Delors, J. et al. 1998, Learning: The treasure within. Report of the International Commission on Education for the Twenty-First Century (The Delors Report), the Australian National Commission for UNESCO, Canberra.

Eisler, D. 2003, 'Foreword', in Marshall B. Rosenberg, Life-Enriching Education, Puddle Dancer Press, Encinitas, Calif.

Foster, L. E. 1981, Australian Education: A sociological perspective, Prentice-Hall, Sydney.

Han Tin 1994, Education for All: Myanmar's country report submitted to EFA experts meeting, Jomtien, the Myanmar National Commission for UNESCO, Yangon.

Han Tin 2000, 'Myanmar education: status, issues and challenges', Challenges in the New Millennium, Journal of Southeast Asian Education/The Official Journal of SEAMEO, vol. 1, no. 1, SEAMEO, Bangkok. 
Han Tin 2004, The school, the teacher, the family and values education, Paper presented at the Conference on Education for Shared Values for Intercultural and Interfaith Understanding, the Australian National Commission for UNESCO, University of Adelaide.

Hattie, J. 2004, 'Teachers make a difference', in Steve Holden, Teachers Matter, Professional Educator, vol. 3, no. 1, March, Australian College of Educators, Deakin.

International Commission on Education for the Twenty-First Century 1996, Learning: The treasure within: Report to UNESCO on Education United Nations Educational, Scientific and Cultural Organization (UNESCO) Publishing, Paris.

James, H. 2005, Governance and Civil Society in Myanmar, Contemporary Southeast Asia Series, Routledge, United Kingdom.

Kennedy, K. 1998, 'Enhancing the status of teachers in the Asia-Pacific region: an exploration of the issues', Asia-Pacific Journal of Teacher Education and Development, vol. 1, no. 1, Institute of Education, Hong Kong.

Kennedy, K. 2004, 'Searching for values in a globalized world: can education provide an answer?', in S. Pascoe (ed.), Values in Education: College Year Book 2002, the Australian College of Educators, Deakin.

Ministry of Education 1992, Education Sector Study-Phase I: Final report [of the Diagnostic Phase], Ministry of Education-UNDP-UNESCO (MYA/90/004 Project), Myanmar Education Research Bureau, Yangon.

Ministry of Education 1993, Education Sector Study-Phase II (Proposal for Education Sector Development. Volumes I and II), Ministry of Education-UNDP-UNESCO (MYA/91/010 Project), Myanmar Education Research Bureau, Yangon.

Ministry of Education 2003, 'Building a modern developed nation through education', Myanmar Education Updates, vol. 2, no. 1, Ministry of Education, Yangon.

Myanmar Education Research Bureau 2003, Review on Adult Education in Myanmar, <www.unesco.org/education/uic/pdf/country/Myanmar.pdf>

Singh, R. R. 1991, Education for the Twenty-first Century: Asia-Pacific perspectives, UNESCO PROAP (APEID), Bangkok.

Than, K. 2006, 'The status of the agricultural sector in Myanmar in 2004', in Trevor Wilson (ed.), Myanmar's Long Road to National Reconciliation, ISEAS-Asia Pacific Press, Singapore. 
United Nations International Children's Emergency Fund (UNICEF) 2005, ‘UNICEF says HIV/AIDS education in Myanmar can save thousands of lives', UNICEF News Note, <http://www.unicef.org/media/media_27322.html>

United Nations Educational, Scientific and Cultural Organisation (UNESCO) 2007, Education Survey, UNESCO Institute of Statistics, Montreal, $<$ http://www.uis.unesco.org >

Win, M. and Batten, G. 2006, 'Sustainable agricultural and rural development: pathways to improving social, economic and environmental conditions in Myanmar', in Trevor Wilson (ed.), Myanmar's Long Road to National Reconciliation, ISEAS-Asia Pacific Press, Singapore.

\section{Endnotes}

${ }^{1}$ Saya San was the leader of the Burmese Peasant Revolt of 1930-31, which was the first concerted effort to resist British domination forcefully.

2 Po Hla Gyi is renowned as the leader of an oil-workers' strike against the British in 1938, and is also the patron saint of traditional Myanmar boxing.

3 Bo Aung Kyaw was a student leader in the All Burma Students Union, who was fatally wounded during a violent protest against the British authorities in December 1938.

${ }^{4}$ U Wisara was a prominent monk who led a resurgence of nationalist sentiment in 1929, was imprisoned by the British colonial authorities and died on a hunger strike in prison.

${ }^{5}$ General Aung San, Aung San Suu Kyi's father, was assassinated in 1947 before he could become independent Burma's first head of state.

6 The Departments of Basic Education for Upper and Lower Myanmar. 